\title{
Baring their souls in online profiles or not? \\ Religious self-disclosure in social media
}

\author{
Piotr S. Bobkowski \\ University of Kansas \\ Lisa D. Pearce \\ University of North Carolina at Chapel Hill
}

Submitted for publication in the Journal for the Scientific Study of Religion

\begin{abstract}
This study measured the prevalence of religious self-disclosure in public MySpace profiles that belonged to a subsample of National Study of Youth and Religion (NSYR) wave 3 respondents $(\mathrm{N}=560)$. Personal attributes associated with religious identification as well as the overall quantity of religious self-disclosures are examined. A majority (62 percent) of profile owners identified their religious affiliations online, although relatively few profile owners (30 percent) said anything about religion outside the religion-designated field. Most affiliation reports (80 percent) were consistent with the profile owner's reported affiliation on the survey. Religious profile owners disclosed more about religion when they also believed that religion is a public matter or if they evaluated organized religion positively. Evangelical Protestants said more about religion than other respondents. Religiosity, believing that religion is a public matter, and the religiosity of profile owners' friendship group were all positively associated with religious
\end{abstract}


identification and self-disclosure.

Keywords: self-disclosure, religious identity, social media, emerging adults.

Individuals' communication about their religious identities and ideas plays an important role in the dissemination of religious knowledge at both the personal and societal levels. For many Americans, however, religious self-disclosure is a fraught proposition. Religion in the United States largely inhabits the private sphere, as it does in other secular societies (Berger 1967). Americans tend not to identify their religious or non-religious affiliations overtly in their everyday interactions. Identifying as religious may be disadvantageous in some social circles, particularly among individuals who spurn organized religion because of the socially conservative positions of many religious institutions (Hout and Fischer 2002; Putnam and Campbell 2010). Yet identifying as an agnostic or an atheist may also be socially detrimental (Edgell et al. 2006). Within religiously homogenous friendship groups, religious self-disclosure may be normative and expected. Young Americans tend to associate being religious with being moral, and agree that being religious can be generally beneficial (Smith and Snell 2009), although they avoid coming across as "too religious" (Smith and Denton 2005). For many Americans, therefore, the act of religious self-disclosure may resemble a tightrope walk, as individuals negotiate their religious identities and the social norms that discourage both overt religious piety and irreligion.

Social media are one public venue in which to observe the enactment of self-disclosure. A growing body of research examines what Internet users say about themselves in social media, especially in social networking websites MySpace and Facebook, and the online and offline implications of this self-disclosure (e.g., Manago et al. 2008; Mikami et al. 2010; Moreno et al. 
2009). As Internet users create personal profiles in social media websites, they are often prompted to self-disclose their religious identities in religion-designated fields and offered the opportunity to articulate their religious perspectives in other portions of the profiles. This study examines religious self-disclosure in these websites. Its first purpose is to measure the prevalence of religious self-disclosure in public MySpace profiles belonging to a general population sample of young adults in the United States. Then, using survey data about the demographic and religious characteristics of these same individuals, the study's goal is to identify personal attributes associated with individuals' religious disclosures. This study contributes to our understanding of religious self-disclosure in both online and offline contexts, and the attributes that may motivate and de-motivate religious expressions.

This study adds to the growing literature on digital religion. Thus far, research examining religion and the Internet has focused primarily on individuals who are somehow dedicated to religion or spirituality, and to communicating about these in online venues (e.g., Campbell 2004, 2010; Lövheim 2004; Richardson 2003). The religious expressions of those "regular" Internet users who may not be as invested in religion have not been carefully examined. Further, previous studies measuring disclosure about religion in social media (Liu 2007; Pempek, Yermolayeva, and Calvert 2009; Young, Dutta, and Dommety 2009) were based on nonrepresentative samples, used one measure of self-disclosure (i.e., religious identification), and were limited to examinations of content without analyses of user characteristics obtained through a sample survey. This study offers a more representative, comprehensive analysis of who is likely to disclose about religion online and how extensively.

This study examines MySpace profiles and survey data of a subsample of National Study of Youth and Religion (NSYR) respondents. Although today Facebook dominates the social 
networking website landscape, the MySpace data examined here represent a point in time when MySpace had a substantial and diverse following among American youth. At the time of data collection (2007-08), MySpace was the third most-popular website in the United States while Facebook was the fifth most-popular website, according to Internet traffic monitoring service alexa.com (Madden, Fox, Smith, and Vitak, 2007). By another measure, MySpace was being visited by more than twice as many U.S. users as Facebook in 2007 (Shonfeld 2007). In addition, until mid-2006 Facebook remained off limits to Internet users who were not affiliated with a university, a high school, or a corporation, while MySpace never restricted its membership. Thus, the MySpace data examined here likely represent a more inclusive sample of American youth than would have comprised a concurrent Facebook sample.

Beyond MySpace and Facebook, this study's findings likely reflect user behaviors in a variety of social websites and applications that prompt members to self-disclose their identities in personal profiles. The study identifies the general contours of religious self-disclosure and the personal attributes that likely compel some people to disclose religiously or to mute such disclosures. These findings are likely not specific to technology-mediated communications and may inform our understanding of religious self-disclosure more broadly.

\section{Conceptual background}

\section{Dimensions of religious self-disclosure}

Self-disclosure can take on variety of formats (Greene, Derlega, and Mathews 2006). Likewise, social media users have several options for self-disclosing about religion in their profiles. Profiles typically contain a specific religion query like the "Religion" field in MySpace, which allows users to choose from a list of religious labels, or Facebook's more open-ended 
"Religious Views" field. Users' first option tends to be, therefore, to succinctly label their beliefs or identify the religious tradition with which they affiliate in such a designated field. Liu (2007) found that in $15.4 \%$ of the MySpace profiles he examined, for instance, the owners identified as "Christian-other."

For some, however, identifying with the label of a specific religious tradition (or none) may be socially undesirable (Bobkowski and Kalyanaraman 2010; Edgell, Gerteis, and Hartmann 2006; Panagopolous 2006), so profile owners may opt not to identify or to identify using a more socially acceptable religious tradition. After all, online communication facilitates enhanced self-presentations (Walther 1996), and most social media users engage in some inaccurate self-portrayals (e.g., Toma, Hancock, and Ellison 2008). Accounting for these three disclosure options - identification, non-identification, or enhanced identification - this study examined the prevalence of religious identification, that is, the succinct religious labeling in the religion-specific field. Further, it compared the consistency with which the online profile label matched what the owner reported in the NSYR survey.

The following research questions guided the first part of the analysis:

RQ 1: What percentage of MySpace users identify religiously in their online profiles?

RQ 2: What religious labels do MySpace users present in their profiles?

RQ 3: How consistent are these online identifications with survey-reported religious affiliations?

Beyond identification, an online profile owner may also opt to articulate his or her religious views or beliefs in open-ended fields like "About Me" or "Interests." Given the possibility of these other religious identity statements in other parts of the profiles, this study measured religious self-disclosure quantity, the volume of religious self-disclosure in which a 
profile owner engaged. The following question summarized this research goal:

RQ 4: Overall, how much religious self-disclosure do young people engage in in their MySpace profiles?

\section{Correlates of religious identification and self-disclosure quantity}

NSYR findings suggest that religion is not a frequent topic of conversation among young people today (Pearce and Denton 2011; Smith and Denton 2005; Smith and Snell 2009). While religion may not be important enough to be discussed in online profiles, what religious selfdisclosure does appear in these profiles is likely shaped through an interplay of discloser, audience, and context characteristics (Leary 1995; Schlenker 2005). Accordingly, this study examined how discloser and audience characteristics were associated with religious identification and the quantity of religious self-disclosure.

Religiosity. Among discloser characteristics, profile owner religiosity, a multidimensional construct involving belief, practice, and salience, is likely to be positively associated with whether, and the extent to which, profile owners engage in religious self-disclosure. Personal characteristics tend to take precedence over audience characteristics when the self-disclosure concerns highly relevant aspects of the self (Schlenker 2005). People who are highly religious will likely identify religiously in their online profiles and say more about their religious selves. Accordingly,

H 1 Profile owners who are more religious (in terms of belief, practice, and salience) will engage in more religious (a) identification, and (b) self-disclosure quantity, than their less religious peers.

Religious affiliation. It is reasonable to expect that individuals who affiliate with some religious groups, regardless of their level of religiosity, will more readily identify as religious 
and say more about religion in their profiles than members of other religious groups. Evangelical Protestants, for instance, may have higher religious self-disclosure rates than individuals affiliated with other groups. Evangelical Protestants may be more motivated to disclose their religious identities and to discuss their faith not only because they tend to score higher than many others on measures of religiosity (Putnam and Campbell 2010), but also because witnessing for the faith is encouraged and expected in some evangelical circles (Stark 2008; Woodberry and Smith 1998). In addition, evangelical Protestants comprise the largest religious "umbrella" group in the United States (e.g., Putnam and Campbell, 2010), which may decrease the social cost of religious self-disclosure among members of this group. Thus,

H 2 Evangelical Protestants engage in more religious (a) identification and (b) overall religious self-disclosure than individuals who affiliate with other religious and nonreligious groups.

Religious attitudes and perceptions. No matter how religious profile owners are, their likelihood and rate of religious self-disclosure may be shaped by their attitudes and perceptions about religion. Those who believe religion is a private matter or have more negative evaluations of organized religion will likely disclose less religious content on their social networking profiles. In addition, the relationship between a profile owner's own religiosity and his/her disclosure of religion will likely be moderated by his or her attitudes about religion.

Everyone manages a set of privacy boundaries around his or her personal information (Petronio, 2002). Although privatized religion is characteristic of secular societies (Berger, 1967), religious privacy boundaries differ by individual. One's privacy boundary may enclose religious information and keep it from being shared with others, or it may leave religion open to public disclosure. Individuals whose privacy boundary contains religion, would be unlikely to 
identify religiously or to talk about religion in their profiles. Even religious individuals who agree that religion is private would be unlikely to identify religiously or talk about religion. These ideas suggest that how private one views religion to be, will be inversely associated with how much he or she discloses about religion. In addition, it is likely that the association between one's own religiosity and the level of disclosure will be modified by views about the privacy of religion. In particular, among the most religious individuals, those who view religion as private are less likely to disclose about their religiosity than those who view religion as something to share publicly.

Another reason someone might choose to not discuss religion online is if he or she has negative feelings toward organized religion and does not want to be associated with it. Further, some individuals distinguish between personal and institutional religious identities. It is possible to consider oneself religious or spiritual but to hold organized religion in low regard. A considerable minority of young adults (i.e., 15-30\%), for instance, identifies as "spiritual but not religious" (Smith and Snell 2009; Wuthnow 2007). Therefore, evaluations of organized religion may also moderate the relationship between personal religiosity and self-disclosure about religion. Individuals who are unenthusiastic about religious institutions but who still consider themselves religious or spiritual may eschew religious labels. They may tend not to identify religiously in their profiles as much as those who are more positive toward organized religion.

The following predictions summarize our expectations in regards to how attitudes and perceptions about religion relate to online disclosure and moderate the relationship between personal religiosity and online disclosure:

H 3 Independent of religiosity, agreeing that religion is private is associated with less religious (a) identification and (b) self-disclosure quantity. 
H 4 The association between religiosity and religious (a) identification and (b) self-disclosure quantity is weaker for profile owners who agree that religion is private than for profile owners who disagree with religion being a private matter.

H 5 Independent of religiosity, negative perception of organized religion is associated with less religious (a) identification and (b) self-disclosure quantity.

H 6 The association between religiosity and online less religious (a) identification and (b) self-disclosure quantity is stronger for profile owners who perceive organized religion more positively.

\section{Perceived social norms}

The primary audience for social media profiles are friends and others whom a profile owner knows offline (Manago et al. 2008; Subrahmanyam et al. 2008). Thus, profile owners are likely to reflect the social norms of their audiences, their offline friendship groups. Social norms of religious friendship groups likely dictate that religious self-disclosure is appropriate and, perhaps, expected. Independent of the discloser's religiosity, friendship group religiosity should be positively associated with religious self-disclosure. Moreover, a number of studies have shown that independent from one's own religiosity, the religiosity of one's friendship group shapes social behavior and attitudes (Adamczyk 2009a, 2009b; Adamczyk and Felson 2006; Adamczyk and Palmer 2008). Therefore, profile owners who are themselves religious and who belong to religious friendship groups may be most likely to disclose religiously in their profiles. Thus,

H 7 Independent of religiosity, friendship group religiosity is associated with more religious (a) identification and (b) self-disclosure quantity.

H 8 Religious profile owners whose friendship groups are more religious engage in more 
religious (a) identification and (b) self-disclosure quantity than religious profile owners whose friendship groups are less religious.

\section{Data and Method}

Sample

This study compared NSYR survey data with the content of NSYR respondents' MySpace profiles. The NSYR began as a nationally representative, random-digit dial (RDD) telephone survey of 3,290 teenagers (13-17 years old) in the United States. Baseline interviews were conducted with teen respondents and one of their parents in 2002-03. Third wave data, examined here, were collected in 2007-08 with 2,458 emerging adults (18-23 years old; 74.7\% of wave 1 teen respondents). For summaries of NSYR methods and findings see Smith and Denton (2005), Pearce and Denton (2011), and Smith and Snell (2009).

MySpace profile data were collected from 560 active, publicly accessible profiles belonging to NSYR wave 3 respondents (22.8\% of wave 3 respondents). Each profile was recorded within 60 days of its owner's survey interview. Respondents were not informed that their publicly accessible profiles were recorded. To ensure the respondents' confidentiality, the content analysis research team did not have access to the survey data. The two datasets were linked only after the content analysis was completed, that is, when all identifying profile information was removed and the remaining profile data were in numeric form. Data collection and analysis procedures were approved by our university’s Institutional Review Board.

To assess the representativeness of the sample on which the analyses were based, the sample of respondents with public MySpace profiles $(N=560)$ was compared to the complete NSYR wave 3 panel on gender, race, region, school, religious salience, religious attendance, and frequency of social networking website use. There were no statistically significant demographic 
or religious differences between the two samples.

\section{Content analysis}

Coders coded all content featured in the front page of each MySpace profile, with the exception of "Friends" and "Friend Comments" sections. The content in these sections was generated by other users, so was not considered self-disclosure. Coders first unitized all content by dividing each profile into a series of utterances. An utterance was a complete phrase or a series of words, or a single word, that signified a unique action (Holsti 1969; Slobin 1993). Each graphic and photo was also identified as a unique utterance. Coders then determined if each utterance was a self-disclosure, that is, if it communicated "personal information about the sender" (Tidwell 1997:225).

Self-disclosures were then assigned to content categories, which included religion/spirituality. Coders were instructed to code as religious any self-disclosures that pertained to religious traditions, activities (e.g., "I worship the Lord daily"), beliefs (e.g., "I'm a Bible believing Christian"), mentions of religious figures (e.g., "Moses is my hero"), symbols and graphics (e.g., crucifix, angels), scripture passages, and mentions of struggles with faith, agnosticism or atheism. Coders were instructed not to code as religious colloquial expressions like "thank God" or "hell no" (definitions adapted from Taylor and Altman 1966; Tidwell 1997).

Four trained coders completed the content analysis. To assess intercoder reliability, all coders coded the same 130 randomly selected profiles (23.2\% of the sample). For each pair of coders and at each step of the coding procedure (i.e., identifying self-disclosures, assigning selfdisclosures to content categories, etc.), reliability was assessed using two measures. First, observed agreement is the proportion of times coders agree. The measure ranges from 0 to 1 , with .80 being a minimum reliability level (Riffe, Lacy, and Fico 2005). Second, Krippendorff's 
alpha measures intercoder agreement while accounting for chance agreement. Alpha ranges from -1 to 1 , with .67 being a minimum reliability level (Riffe et al. 2005). All intercoder reliabilities for measures reported here exceeded the minimum reliability levels.

\section{Dependent variables}

Religious identification was a dichotomous variable, indicating whether the profile owner identified him/herself using one of the 14 labels in the profile's "Religion" field. MySpace provided these possible labels: "Agnostic," "Atheist," "Buddhist," "Catholic," "Christian-other," "Hindu," "Jewish," “Mormon," "Muslim," “Other," "Protestant," “Scientologist," “Taoist," and "Wiccan." MySpace did not allow open-ended identification in this field.

The MySpace "Religion" label was coded consistent if it matched the respondent's survey-reported religious affiliation. Because MySpace users seemed to interpret the "Christianother" label to signify a general Christian identity, the "Christian-other" label was coded consistent if it corresponded to Catholic, Protestant, Orthodox, or Mormon/LDS affiliation in the survey.

Religious self-disclosure quantity was the overall number of self-disclosures in a profile that referenced religion or spirituality. Descriptive statistics for this variable are presented at the start of the Results section.

\section{Control variables}

Table 1 presents definitions and descriptive statistics for all control and independent variables. Control variables drawn from the survey included demographics (gender, age, ethnicity, family income at wave 1, highest level of education) and social networking website use frequency. Missing values (less than two on most variables) were imputed with Amelia II, a multiple imputation program (Honaker, King, and Blackwell, n.d.). 
Profile owners who engaged in more self-disclosure overall were more likely to include religion among their disclosures. Two measures, one for each of the dependent variables, accounted for profile owners' overall self-disclosure. Overall identification was the number of content categories (out of ten, religion not included) that self-disclosures in the profile represented. Overall quantity was the total number of self-disclosures contained in the profile, excluding religious self-disclosures.

\section{Independent variables}

Religiosity was measured with a three-item additive scale, with dichotomous items corresponding to the belief, practice, and salience dimensions (see Table 1 for question wording and descriptive statistics). The scale was reliable (Cronbach's $\alpha=.77$ ).

Religious affiliation was based on the "reltrad" categorization (Steensland et al. 2000), which assigned respondents' affiliations based on place of religious attendance, self-affiliation, and parent affiliation. Protestant Christians were categorized as either mainline or evangelical. Race-specific Christian designations (i.e., Black evangelical Protestant, White evangelical Protestant) were collapsed because of a low frequency in the Black mainline Protestant category $(N=4)$. Respondents who identified as atheist and agnostic were differentiated from those who identified as not religious.

Religion is private was measured with one religious privacy question; negative perception of organized religion was measured with two correlated questions (see Table 1 for question wording and descriptive statistics). Each of these questions was originally measured with a five-point scale ( $1=$ "Strongly agree" $\ldots 5=$ "Strongly disagree"), with the middle item not read by the telephone interviewer and resulting in low frequencies at the midpoint. The items were recoded onto a 4-point scale, after merging the original midpoint with the original $4=$ 
"Disagree." Friendship group religiosity was the proportion of the profile owner's closest friends (up to five) who were religious.

Analysis strategy

Logistic regression models were estimated for religious identification. Because religious self-disclosure quantity was a highly skewed count variable (consisted of zeros and nonnegative integers), negative binomial regression models were used. To facilitate interpretation, incidence rate ratios (IRR) were calculated. Analogous to odds ratios (OR) in logistic regression, IRR indicate the rate (or count) change of the dependent variable associated with a one-unit increase in the predictor variable (Atkins \& Gallop, 2007; Coxe, West, \& Aiken, 2009).

[Table 1 about here]

\section{Results}

Addressing RQ 1, the analysis showed that a majority of the MySpace users displayed a religious identity in the "Religion" field of their profiles $(N=348,62.1 \%)$. Table 2 presents the frequencies with which "Religion" field labels were used. Addressing RQ 2, most of those who identified in the "Religion" field, displayed the "Christian-other" label $(N=202,58.0 \%)$. "Catholic" was the second-most frequently used label $(N=63,17.8 \%)$. Although about half of the survey respondents were categorized as either evangelical or mainline Protestants, only nine profile owners displayed the label "Protestant." Also interestingly, more than a third $(N=43$, $39.8 \%$ ) of those who did not identify as religious on the survey used one of the "Religion" MySpace labels in their profiles; only four of these used the "Agnostic" or "Atheist" labels.

[Table 2 about here]

Table 2 also shows the frequencies with which "Religion" labels were used within each 
NSYR religious affiliation category. With regard to RQ 3, most of the online identifications were consistent with the religious affiliations that profile owners reported in the NSYR survey $(N=$ 277, 79.6\%). Almost all Catholics who displayed a "Religion" label in their profiles used a consistent label, identifying either as "Catholic" (53 of 62, 85.5\%) or as "Christian-other" $(N=8$, 12.9\%). Likewise, almost all evangelical and mainline Protestants identified consistently, using the "Christian-other" label (evangelical: 136 of 152, 89.5\%; mainline: 33 of 38, 86.8\%), or the "Protestant" label (evangelical: $N=7,4.6 \%$; mainline: $N=2,5.3 \%$ ). Respondents who affiliated with smaller groups also tended to identify consistently: Jewish (5 of 6, 83.3\%), Mormon/LDS (7 of $8,87.5 \%$ ), atheist (9 of $13,69.2 \%)$.

Turning to overall self-disclosure, coders identified 56,462 self-disclosures in all, ranging from 1 to 805 per profile $(M=100.82, S D=84.94)$. With regard to RQ 4, religious selfdisclosure was not frequent when measured in the context of all the other self-disclosures displayed in the profiles. Although more than two-thirds $(392,70.0 \%)$ of the profiles contained at least one religious self-disclosure, there were only 925 religious self-disclosures in all, comprising $1.64 \%$ of all the self-disclosures examined. Religious self-disclosure quantity ranged from 0 to 47 per profile, with an average of 1.65 such disclosures per profile $(S D=3.20)$. Only $30.4 \%$ of the profiles contained any religious self-disclosures outside the "Religion" field. This means that the majority of profile owners who engaged in religious self-disclosure only identified their religious affiliation using the predetermined labels of the "Religion" field but did not say anything further about their religious identity. There was a modest correlation between religious identification and self-disclosure quantity $(r=.30, p<.001)$.

Addressing the hypotheses, religiosity was positively associated with the likelihood to identify $(B=.38, S E=.08, p<.001)$, and with religious self-disclosure quantity $(B=.42, S E=$ 
$.05, p<.001)$ (Table 3, columns 1-2). A one-unit increase in religiosity corresponded with a $47 \%$ increase in the likelihood to identify, and a $52 \%$ increase in the quantity of religious selfdisclosure. Thus, H 1 a and b were supported.

Respondents who were unaffiliated in the survey were half as likely as evangelical Protestants to identify using the "Religion" label $(B=-.69, S E=.34, p<.05)$. None of the other affiliation categories were associated with the likelihood to identify (Table 3, column 3). Thus, H 2a was only supported for survey respondents who were unaffiliated.

Three affiliation categories were associated with religious self-disclosure quantity (Table 3, column 4). Mainline Protestants disclosed at a $44 \%$ lower rate than evangelical Protestants ( $B$ $=-.57, S E=.18, p<.01)$. Catholics disclosed at a $42 \%$ lower rate than evangelical Protestants $(B=-.54, S E=.15, p<.001)$. The unaffiliated disclosed at $34 \%$ lower rate than evangelical Protestants $(B=-.41, S E=.20, p<.05)$. Thus, $\mathrm{H} 2 \mathrm{~b}$ was supported for these three categories. In analyses not shown here, we also used mainline Protestants and Catholics as the reference groups instead of evangelical Protestants, but there were no statistically significant associations between any of the affiliation groups and religious self-disclosure in these models.

[Table 3 about here]

A one-unit increase in agreeing that religion is private was associated with a $22 \%$ decrease in the likelihood to identify $(B=-.25, S E=.12, p<.05)$, and with a $30 \%$ decrease in the rate of religious self-disclosure $(B=-.35, S E=.06, p<.001)$ (Table 4, columns 1, 3). H 3a and $b$ were supported.

As Figure 1a illustrates, there was no interaction between religiosity and agreeing that religion is private for religious identification (Table 4, column 2). H 4a was not supported. The interaction between religiosity and agreeing that religion is private was associated negatively 
with religious self-disclosure quantity. As predicted in $\mathrm{H} 4 \mathrm{~b}$ and illustrated in Figure $1 \mathrm{~b}$, religious profile owners who agreed that religion is private self-disclosed at a lower rate than equally religious profile owners who thought religion is not private $(B=-.14, S E=.06, p<.01)$ (Table 4, column 4).

[Table 4 about here]

[Figure 1 about here]

Negative perception of organized religion was not directly associated with either of the dimensions of religious self-disclosure (Table 5, columns 1, 3). Neither H 5 a nor b was supported. The interaction between religiosity and negative perception of organized religion was statistically significant for both the likelihood to identify $(B=-.30, S E=.12, p<.05)$ and the rate of religious self-disclosure quantity $(B=-.21, S E=.07, p<.01)$ (Table 5, columns 2,4$)$. Therefore, $\mathrm{H} 6$ a and b were supported. As illustrated in Figures 2a and b, a negative perception of organized religion appeared to mute the positive associations between religiosity and both the likelihood to identify religiously and the rate of religious self-disclosure.

[Table 5 about here]

[Figure 2 about here]

Profile owners with all religious friends were $199 \%$ more likely to identify religiously than profile owners who did not have any religious friends $(B=1.09, S E=.28, p<.001)$ (Table 6 , column 1). Those with religious friends disclosed about religion at a $123 \%$ higher rate than profile owners who did not have any religious friends $(B=.80, S E=.15, p<.001)$ (Table 6 , column 3). Thus, H $7 \mathrm{a}$ and $\mathrm{b}$ were supported. As illustrated in Figures $3 \mathrm{a}$ and b, however, the interactions between religiosity and friendship group religiosity were not significant for either of the religious self-disclosure dimensions (Table 6, columns 2, 4). 
[Table 6 about here]

[Figure 3 about here]

\section{Discussion}

\section{Religious self-disclosure online}

This study examines religious self-disclosure in public MySpace profiles belonging to a sample of young adults, and analyzes the link between the sample's religious disclosure and its demographic and religious characteristics. The study's results contribute to our understanding of the prevalence and process of religious self-disclosure in both online and offline contexts.

The study's findings show that many online users choose to self-disclose a religious affiliation in their profiles. Most, however, do not divulge much more than that about their religious and spiritual lives. Those who do say more about religion are considerably invested in religion, that is, they are religious and believe that religion is a public matter or view organized religion positively, or are in like-minded religious friendship groups. These findings are generally in line with how Smith and Denton (2005) and Pearce and Denton (2011) report overall articulation of religious identity in face-to-face, semi-structured interviews with youth.

More than $60 \%$ of the MySpace users identified religiously using a label in the "Religion" field. The majority (58\%) of the profile owners who identified in the "Religion" field

used the "Christian-other" label. In a classification scheme that includes the terms "Catholic" and "Protestant," the label "Christian-other" would have been meant for Christians who are neither Catholic nor Protestant (e.g., Greek Orthodox). According to the survey, however, most of those who identified as "Christian-other" were either evangelical or mainline Protestant. While it is beyond the scope of this study to consider what motivated individuals to gravitate toward the 
“Christian-other" label (i.e., post-denominationalism, religious illiteracy, primacy artifact, etc.), researchers who study religious identity should be mindful of that young people today appear to have low familiarity with, or level of attachment for the term "Protestant."

Most of the religious identifications in the "Religion" field (nearly 80\%) were consistent with the profile owners' religious affiliations in the survey. Profile owners apparently control the presentation of their religious identities through nondisclosure rather than through inconsistent disclosure. Other research has similarly shown that online identity experiments among young Internet users are rare (e.g., Gross 2004), and that deceitful information, although present in many personal profiles, is generally not pervasive (e.g., Toma et al. 2008). This study's data suggest that once individuals decide to identify their religious identities, they tend not to shift these identities to fit different disclosure contexts.

This study also shows that most online profile owners do not engage in lengthy or indepth religious self-disclosures. Fewer than one-in-three profile owners say something about religion on their own, outside the single-word "Religion" field. Most of what young people say about religion in their profiles appears to be brief, superficial, and prompted by the presence of a drop-down menu listing religious affiliation options. Spontaneous disclosure about religion is rare. Future research should examine whether this changes with age or holds true for all individuals.

\section{Discloser and audience characteristics}

The relative absence and superficiality of religious self-disclosure in online profiles may reflect the privatized nature of religion in secularized societies (Berger 1967), the cultivated deficit of religious rhetoric characteristic of public discourse in the United States (Carter 1993; Casanova 2003), apprehension about being identified with conservative social issues (Putnam 
and Campbell 2010), and young people's indifference toward religion (Smith and Snell 2009). This study identifies specific characteristics - affiliations, attitudes and norms - that appear to motivate some people and de-motivate others to engage in religious self-disclosure in online profiles.

Profile owners who are more religious are more likely than less religious profile owners to identify religiously and to disclose more about religion overall. Contrary to expectations, however, the analysis also suggests that evangelical Protestants are no more likely than members of other religious and nonreligious groups to identify their religious identities online. Only unaffiliated individuals (who are not agnostic or atheist) appear significantly less likely than evangelical Protestants to identify in their profiles, but "None" is not one of the "Religion" label options in MySpace. Mainline Protestants and Catholics, as well as the nonreligious, disclose significantly less overall about religion than evangelical Protestants. Evangelical Protestantism's tradition of public evangelism and the group's relative size may contribute to its members' willingness to say more about religion than mainline or Catholic Christians. Further research is necessary to understand more specifically what motivates evangelical Protestants' greater religious self-disclosure.

Two religion-related attitudes, belief that religion is a private matter and having a negative perception of organized religion, also appear to be associated with religious selfdisclosure. The attitude that religion is a private matter is directly associated with increased identification and overall disclosure. This attitude also moderates the relationship between religiosity (as reported in the survey) and disclosure, such that the most religious individuals tend to disclose little about religion if they believe that religion is a private matter. Having a negative view of organized religion is also directly associated with decreased religious identification. In 
addition, the most religious profile owners tend not to identify their affiliations, and tend to disclose little overall about religion, if they view organized religion negatively.

These muted religious self-disclosures among individuals who would be otherwise expected to disclose abundantly, suggest that these profile owners undertake self-presentational shifts toward more socially desirable portrayals. Such shifts result from a mismatch between the image that they desire to project - in this case, one that does not endorse public displays of religion or organized religion - and the image they imagine to be projecting - one that does endorse public and organized religion (Leary 1995; Leary and Kowalski 1990). Therefore it is not always religiosity itself that is directly associated with religious self-disclosure, but religiosity in someone who sees value in religion being public and has positive perceptions of organized religion.

The importance of the relationship between social norms and self-disclosure is underscored in the direct associations between friendship group religiosity and religious selfdisclosure. Regardless of how religious they are, profile owners whose closest friends are religious are more likely to identify and to self-disclose at a higher rate than those whose closest friends are not religious. Friends likely model self-disclosure-related norms in their profiles, setting expectations for the appropriate self-disclosure. With offline friends making up the majority of the audience for a social media profile (Manago et al. 2008; Subrahmanyam et al. 2008), friendship groups may "warrant," or check on the accuracy of individuals' online claims (Walther and Parks 2002). These findings are also in line with other studies of the influence of peer religiosity on one's own religiosity. When individuals have peers who are more religious, they tend to stay or become more religious themselves (Pearce and Denton 2011; Regnerus and Uecker 2006). 
Of course, caution is warranted in interpreting these results as evidence of the causal influence of discloser and audience characteristics on online religious self-disclosure. Although the profiles analyzed here were collected no more than 60 days before or after their profile owners' survey interviews, the exact time order cannot be established. The causal links suggested here must remain speculative and the possibility cannot be rejected that it is the online disclosure that affects the discloser's survey-reported religiosity. Studies show that social website users express their aspirational selves in their profiles (Manago et al. 2008), and that enacting a particular trait in online forums may lead to the internalization of that trait (Gonzales and Hancock 2008).

\section{Implications and future research}

Although this project is a very important step toward understanding the "doing" of religion in online interactions and, more broadly, religious self-disclosure, this work can be improved upon in the future. This study examined discrete, static self-disclosures outside the context of any ongoing communications. The predictors of self-disclosure were likewise conceptualized as fixed and stable. Associations between predictors and disclosures were modeled as linear and unidirectional. In reality, self-disclosure is an ongoing, transactional process (Dindia 1997). Future studies should employ longitudinal measurement methods to account for the dialogical, developing nature of religious self-disclosure over time.

In addition, the content analysis measures used here provided a broad overview of what religious self-disclosure looks like in online profiles, which is important for representing the range and depth of what is happening across the population of emerging adults in the United States. This account glossed over, however, any distinctions in the tone or valence of individual disclosures. A few profile owners approached religious ideas somewhat playfully and 
irreverently. One, for instance, wrote in the "Who I'd like to meet" field, "God, so I can punch him for being such a screw up." Another displayed a graphic with the tagline, "I found Jesus! He was behind the couch!" Although such non-deferential self-disclosures were very infrequent, the data examined here deserve a qualitative analysis that would identify the nuances of religious self-disclosure that were missed in this broadly focused study.

Two broad conclusions emerge from this study. First, social media users rarely disclose much about religion in their online profiles and when they do, their disclosures tend to be brief and superficial. Previous research suggests that offline discourse about religious beliefs and views among adolescents and emerging adults is equally lacking (Pearce and Denton 2011; Smith and Denton 2005; Smith and Snell 2009). Second, religious self-disclosure is the product of a self-presentational process that weighs discloser identities and audience characteristics. Profile owner religiosity, attitudes about religion's place in society, and friend religiosities - and likely other attributes not measured here - are associated with the incidence and character of religious self-disclosure in the social media profile.

Such a dearth of religious self-disclosure and limited religious discourse at the interpersonal level certainly may contribute to high levels of religious illiteracy in the United States (Dean 2010; Prothero 2007; Pew Forum on Religion \& Public Life 2010), and to the perpetuation of religious assumptions and stereotypes. Sorting out what it means to be religious or nonreligious as an individual and as a society cannot take place without open communication about religious ideas and identities. Religious self-disclosures can serve as entries into dialogue about religion, spirituality, and the beliefs and practices of variously religious and nonreligious people that inform this society's religion-related perceptions and misperceptions.

This study's findings suggest, however, that whatever religious discourse and dialogue 
exist, these are dominated by individuals who are invested in religion. If patterns of religious self-disclosure in online profiles reflect patterns of religious expression in other contexts, then the dominant religious issues and their framing reflect the views and attitudes of individuals who are highly religious, believe that religion is a public matter, hold religious organizations in high regard, and have religious friends. The views and ideas of those individuals who are less religious or who do not endorse public religion or religious organizations, probably play a lesser role in public discourse about religion. Further research focusing on the process of religious selfdisclosure has the potential to highlight the shortcomings of how religious ideas and identities are currently expressed, and inform initiatives for improving communication about religion and religious identity.

Online profiles have the potential to generate a space and a language that might allow individuals to self-disclose and communicate religiously in ways that are unfeasible in offline contexts. Evidence of this can be found on the vastly popular social networking site, Facebook, where "Religious Views" is an open-ended field limited to 100 characters (Wan 2009). The focused yet open-ended nature of Facebook's "Religious Views" field encourages religious selfdisclosures that can be tailored to deflect any stigma or negative associations (i.e., negative perceptions of organized religion) that profile owners might otherwise be hesitant to generate. With no offline equivalent, the "Religious Views" field and the self-disclosures it encourages has the capacity to provoke unique questions and discourse about religion.

This study presents baseline data and suggests a framework on which a religious selfdisclosure research agenda might be built. Such research should explore further the two sets of attributes examined here - discloser and audience characteristics - and expand the scope of inquiry to include the context of the disclosure. Individual discloser characteristics not included 
in this study that may influence the likelihood and character of religious self-disclosure include extraversion (Archer 1979; Peter, Valkenburg, and Schouten 2005), self-monitoring (Shaffer, Smith, and Tomarelli 1982), and privacy standards (Petronio 2002). Since a self-disclosure generally constitutes one node in an ongoing conversation, discloser motivations for the immediate situation or the broader relationship must be carefully considered. The influence of audience characteristics may best be examined in controlled experimental studies that allow for the manipulation of audience attributes, and for the measurement of associated selfpresentational shifts (e.g., Walther 2007). Although the technology-mediated context of selfdisclosure is important to explore further, especially as individuals increase their dependence on technological devices to develop and maintain relationships, research also needs to fully address the incidence and character of religious self-disclosure outside of the technological setting (e.g., through physical attire; Long and Long 1976). Understanding more fully the process of religious self-disclosure is key to understanding how religious identity and broader religious ideas are shaped and communicated in society. 


\section{References}

Adamczyk, Amy. 2009a. Socialization and selection in the link between friends' religiosity and the transition to sexual intercourse," Sociology of Religion 70(1):5-27.

Adamczyk, Amy. 2009b. Understanding the effects of personal and school religiosity on the decision to abort a premarital pregnancy. Journal of Health and Social Behavior 50(2):18095.

Adamczyk, Amy, and Jacob Felson. 2006. Friends' religiosity and first sex. Social Science Research 35(4):924-47.

Adamczyk, Amy, and Ian Palmer. 2008. Religion and initiation into marijuana use: The deterring role of religious friends. Journal of Drug Issues 38(3):717-42.

Archer, Richard L. 1979. Role of personality and the social situation. In Self-disclosure: Origins, patterns, and implications of openness in interpersonal relationships, edited by Gordon I. Chelune and Associates, pp. 28-58. San Francisco: Jossey-Bass.

Atkins, David C., and Robert J. Gallop. 2007. Rethinking how family researchers model infrequent outcomes: A tutorial on count regression and zero-inflated models. Journal of Family Psychology 21(4):726-35.

Berger, Peter L. 1967. The sacred canopy: Elements of a sociological theory of religion. New York: Doubleday.

Bobkowski, Piotr S., and Sriram Kalyanaraman. 2010. Effects of online Christian self-disclosure on impression formation. Journal for the Scientific Study of Religion 49(3):456-76.

Campbell, Heidi A. 2004. Exploring religious community online. New York: Peter Lang.

-----. 2010. When religion meets new media. New York: Routledge. 
Carter, Stephen L. 1993. The culture of disbelief: How American law and politics trivialize religious devotion. New York: Anchor Books.

Casanova, José. 2003. What is a public religion? In Religion returns to the public square: Faith and policy in America, edited by Hugh Heclo and Wilfred M. McClay, pp. 111-39. Washington, D.C.: Woodrow Wilson Center Press, and Baltimore, MD: The Johns Hopkins University Press.

Coxe, Stefany, Stephen G. West, and Leona S. Aiken. 2009. The analysis of count data: A gentle introduction to Poisson regression and its alternatives. Journal of Personality Assessment 91(2):121-36.

Dean, Kenda Creasy. 2010. Almost Christian: What the faith of our teenagers is telling the American church. New York: Oxford University Press.

Dindia, Kathryn. 1997. Self-disclosure, self-identity, and relationship development: A transactional/dialectical perspective. In Handbook of personal relationships: Theory, research and interventions, edited by Steve Duck, pp. 411-26. New York: John Wiley \& Sons.

Edgell, Penny, Joseph Gerteis, and Douglas Hartmann. 2006. Atheists as “other”: Moral boundaries and cultural membership in American society. American Sociological Review 71(2):211-34.

Gonzales, Amy L., and Jeffrey T. Hancock. 2008. Identity shift in computer-mediated environments. Media Psychology 11(2):167-85.

Greene, Kathryn, Valerian J. Derlega, and Alicia Mathews. 2006. Self-disclosure in personal relationships. In The Cambridge Handbook of Personal Relationships, edited by Anita L. Vangelisti and Daniel Perlman, pp. 409-27. New York: Cambridge University Press. 
Gross, Elisheva F. 2004. Adolescent Internet use: What we expect, what teens report. Applied Developmental Psychology 25(6):633-49.

Holsti, Ole R. 1969. Content analysis for the social sciences and humanities. Reading, MA: Addison-Wesley.

Honaker, James, Gary King, and Matthew Blackwell. n.d. Amelia II: A program for missing data. Available at http://gking.harvard.edu/amelia

Kosmin, Barry A. and Ariela Keysar. 2009. American religious identification survey (ARIS 2009): Summary report. Hartford, CT: Trinity College.

Leary, Mark R. 1995. Self-presentation: Impression management and interpersonal behavior. Madison, WI: Brown \& Benchmark.

Leary, Mark R., and Robin M. Kowalski. 1990. Impression management: A literature review and two-component model. Psychological Bulletin 107(1):34-47.

Liu, Hugo. 2007. Social network profiles as taste performances. Journal of Computer-Mediated Communication 13(1):252-75.

Long, Lynette N., and Thomas J. Long. 1976. Influence of religious status and religious attire on interviewees. Psychological Reports 39(1):25-26.

Lövheim, Mia. 2004. Young people, religious identity, and the Internet. In Religion online: Finding faith on the Internet, edited by Lorne L. Dawson and Douglas E. Cowan, pp. 5974. New York: Routledge.

Madden, Mary, Susannah Fox, Aaron Smith, and Jessica Vitak. 2007. Digital footprings: Online identity management and search in the age of transparency. Available at http://pewinternet.org/Reports/2007/Digital-Footprints.aspx. 
Manago, Adriana M., Michael B. Graham, Patricia M. Greenfield, and Goldie Salimkhan. 2008. Self-presentation and gender on MySpace. Journal of Applied Developmental Psychology 29(6):446-58.

Mikami, Amori Yee, David E. Szwedo, Joseph P. Allen, Meredyth A. Evans, and Amanda L. Hare. 2010. Adolescent peer relationships and behavior problems predict young adult communication on social networking websites. Developmental Psychology 46(1):46-56.

Moreno, Megan A., Malcolm R. Parks, Frederick J. Zimmerman, Tara E. Brito, and Dimitri A. Christakis. 2009. Adolescents' display of health risk behaviors on MySpace: Prevalence and associations. Archives of Pediatrics and Adolescent Medicine 163(1):27-34.

Panagopolous, Costas. 2006. Arab and Muslim Americans and Islam in the aftermath of 9/11. Public Opinion Quarterly 70(4):608-24.

Pempek, Tiffany A., Yevdokiya A. Yermolayeva, and Sandra L. Calvert. 2009. College students' social networking experiences on Facebook. Journal of Applied Developmental Psychology 30(3):227-38.

Pearce, Lisa D. and Melinda Lundquist Denton. 2011. A faith of their own: Stability and change in the religiosity of America's adolescents. New York: Oxford University Press.

Peter, Jochen, Patti M. Valkenburg, and Alexander P. Schouten. 2005. Developing a model of adolescent friendship formation on the Internet. CyberPsychology \& Behavior 8(5):423-30.

Petronio, Sandra. 2002. The boundaries of privacy: Praxis of everyday life. In Boundaries of privacy: Dialectics of disclosure, edited by Sandra Petronio, pp. 37-56. Albany, NY: State University of New York Press.

Pew Forum on Religion and Public Life. 2010. U.S. Religious knowledge survey. Available at http://pewforum.org/Other-Beliefs-and-Practices/U-S-Religious-Knowledge-Survey.aspx. 
Prothero, Stephen. 2007. Religious literacy: What every American needs to know-and doesn't. New York: HarperOne.

Putnam, Robert D., and David E. Campbell. 2010. American grace: How religion divides and unites us. New York: Simon \& Schuster.

Regnerus, Mark D., and Jeremy E. Uecker. 2006. Finding faith, losing faith: The prevalence and context of religious transformations during adolescence. Review of Religious Research 47:217-237.

Richardson, John D. 2003. Uses and gratifications of agnostic refuge: Case study of a skeptical online congregation. Journal of Media and Religion 2(4):237-50.

Riffe, Daniel, Stephen Lacy, and Frederick G. Fico. 2005. Analyzing media messages: Using quantitative content analysis in research. 2nd ed. Mahwah, NJ: Lawrence Erlbaum.

Schonfeld, Eric. 2007. Social site rankings. Tech crunch. Retrieved 7 October, 2010. Available at http://techcrunch.com/2007/11/28/social-site-rankings-october-2007

Schlenker, Barry R. 2005. Self-presentation. In Handbook of self and identity, edited by Mark R. Leary and June Price Tangney, pp. 492-518. New York: Guilford Press.

Shaffer, David R., Jonathan E. Smith, and Michele Tomarelli. 1982. Self-monitoring as a determinant of self-disclosure reciprocity during the acquaintance process. Journal of Personality and Social Psychology 43(1):163-75.

Slobin, Dan I. 1993. Coding child language data for crosslinguistic analysis. In Talking data: Transcription and coding in discourse research, edited by Jane Anne Edwards and Martin D. Lampert, pp. 207-19. Hillsdale, NJ: Lawrence Erlbaum.

Smith, Christian with Melinda L. Denton. 2005. Soul searching: The religious and spiritual lives of American teenagers. New York: Oxford University Press. 
Smith, Christian with Patricia Snell. 2009. Souls in transition: The religious \& spiritual lives of emerging adults. New York: Oxford University Press.

Stark, Rodney. 2008. What Americans really believe. Waco, TX: Baylor University Press.

Steensland, Brian, Jerry Z. Park, Mark D. Regnerus, Lynn D. Robinson, W. Bradford Wilcox, and Robert D. Woodberry. 2000. The measure of American religion: Improving the state of the art. Social Forces 79(1):291-318.

Subrahmanyam, Kaveri, Stephanie M. Reich, Natalia Waechter, and Guadalupe Espinoza. 2008.

Online and offline social networks: Use of social networking sites by emerging adults. Journal of Applied Developmental Psychology 29(6):420-433.

Taylor, Dalmas A. and Irwin Altman. 1966. Intimacy-scaled stimuli for use in studies of interpersonal relationships. Research Report No. 9. Bethesda, MD: Naval Medical Research Institute.

Tidwell, Lisa Collins. 1997. A comparison of anticipated interaction, channel, and communication goal on impression formation, self-disclosure, and relational orientation: Getting to know one another a bit at a time (Doctoral dissertation, Northwestern University). Dissertation Abstracts International 58:4128.

Toma, Catalina L., Jeffrey T. Hancock, and Nicole B. Ellison. 2008. Separating fact from fiction: An examination of deceptive self-presentation in online dating profiles. Personality and Social Psychology Bulletin 34(8):1023-36.

Wan, William. 2009. Soul-searching on Facebook: For many users, religion question is not easy to answer. The Washington Post Aug. 30:A1.

Walther, Joseph. B. 1996. Computer-mediated communication: Impersonal, interpersonal, and hyperpersonal interaction. Communication Research 23(1):3-43. 
-----. 2007. Selective self-presentation in computer-mediated communication: Hyperpersonal dimensions of technology, language, and cognition. Computers in Human Behavior 23(5):2538-57.

Walther, Joseph B. and Malcolm R. Parks. 2002. Cues filtered out, cues filtered in. In Handbook of Interpersonal Communication, edited by Mark L. Knapp and John A. Daly, pp. 529-63. Thousand Oaks, CA: Sage.

Woodberry, Robert D. and Christian C. Smith. 1998. Fundamentalism et al: Conservative Protestants in America. Annual Review of Sociology 24(1):25-56.

Wuthnow, Robert. 2007. After the Baby Boomers: How the twenty-and thirty-somethings are shaping the future of American religion. Princeton, NJ: Princeton University Press.

Young, Sean, Debo Dutta, and Gopal Dommety. 2009. Extrapolating psychological insights from Facebook profiles: A study of religion and relationship status. CyberPsychology \& Behavior 12(3):347-50. 


\section{Table 1}

Definitions and Descriptive Statistics of Control and Independent Variables (NSYR Wave 3 Respondents With Public MySpace Profiles, $N=560$ )

\begin{tabular}{|c|c|c|}
\hline Measure & Description (Range) & $M$ or $\%(S D)$ \\
\hline \multicolumn{3}{|l|}{ Control variables } \\
\hline Gender & Female $(0=$ male, $1=$ female $)$ & $46.9 \%$ \\
\hline Age & Age in years (18 to 23$)$ & $20.02(1.43)$ \\
\hline Ethnicity & White $(0=$ non-White, $1=$ White $)$ & $70.2 \%$ \\
\hline Family income & $\begin{array}{l}\text { Parent-reported family income at wave } 1(2002-03)(0=\text { "Less than } \$ 10 \mathrm{~K} " \ldots 11= \\
\text { "More than } \$ 100 \mathrm{~K} ")\end{array}$ & $6.11(2.70)$ \\
\hline Education & $\begin{array}{l}\text { Highest level of education achieved ( } 0=\text { "Less than high school" } \ldots 4=\text { "College } \\
\text { graduate" or higher) }\end{array}$ & $2.44(.78)$ \\
\hline $\begin{array}{l}\text { Soc. networking } \\
\text { frequency }\end{array}$ & Frequency of SNS use ( $0=$ "Never" $\ldots 6=$ "Several times a day") & $3.83(1.88)$ \\
\hline $\begin{array}{l}\text { Overall } \\
\text { identification }\end{array}$ & $\begin{array}{l}\text { Number of content categories (current events/affairs, education/work, } \\
\text { interests/pastimes/habits, media preferences, money/material possessions, non- } \\
\text { romantic relationships, physical appearance, romantic relationships, other } \\
\text { biographic information, other) that self-disclosures in the profile represent ( } 0 \text { to 10) }\end{array}$ & $7.52(1.12)$ \\
\hline Overall quantity & Total number of self-disclosures in a profile, excluding religious self-disclosures & $99.17(84.21)$ \\
\hline \multicolumn{3}{|c|}{ Independent variables } \\
\hline \multirow[t]{3}{*}{ Religiosity } & Three-item religiosity scale ( $0=$ least religious $\ldots 3=$ highly religious) $(\alpha=.77)$ & $2.06(1.14)$ \\
\hline & "Do you believe in God?" (0 = “No" or "Uncertain,” 1 = "Yes") & $76.3 \%$ \\
\hline & $\begin{array}{l}\text { "Do you attend religious services more than } 1-2 \text { times a year, not counting } \\
\text { weddings, baptisms, and funerals?" }(0=\text { "No," } 1=\text { "Yes") } \\
\text { "How important or unimportant is religious faith in shaping how you live your } \\
\text { daily life?" }(0=\text { "Not very" or "Not at all," } 1=\text { = Somewhat" to "Extremely } \\
\text { important") }\end{array}$ & $69.5 \%$ \\
\hline \multirow[t]{9}{*}{ Affiliation } & Evangelical Protestant & $40.2 \%$ \\
\hline & Mainline Protestant & $10.5 \%$ \\
\hline & Catholic & $15.2 \%$ \\
\hline & Jewish & $1.1 \%$ \\
\hline & Mormon/LDS & $2.0 \%$ \\
\hline & Other & $3.2 \%$ \\
\hline & Agnostic & $5.4 \%$ \\
\hline & Atheist & $3.2 \%$ \\
\hline & Unaffiliated & $19.3 \%$ \\
\hline Religious privacy & $\begin{array}{l}\text { "Religion is a private matter that should be kept out of public debates about social } \\
\text { and political issues" ( } 1=\text { "Strongly disagree" } \ldots 4=\text { "Strongly agree") }\end{array}$ & $2.73(.87)$ \\
\hline $\begin{array}{l}\text { Negative } \\
\text { perception of } \\
\text { organized } \\
\text { religion }\end{array}$ & $\begin{array}{l}\text { "I have a lot of respect for organized religion in this country" (reversed), and } \\
\text { "Organized religion is usually a big turn-off for me" ( } 1=\text { "Strongly disagree" } \ldots 4 \\
=\text { "Strongly agree") }(r=.44, p<.001)\end{array}$ & $2.21(.71)$ \\
\hline $\begin{array}{l}\text { Friendship group } \\
\text { religiosity }\end{array}$ & $\begin{array}{l}\text { Proportion of closest friends (up to five) who are religious ("How many, if any, of } \\
\text { these people are religious?") }(0-1)\end{array}$ & $.52(.38)$ \\
\hline
\end{tabular}


Table 2

Religious Affiliation and MySpace Identification Frequencies (NSYR Wave 3 Respondents With Public MySpace Profiles, $N=560$ )

Religious identification in MySpace ("Religion" field label)

\begin{tabular}{|c|c|c|c|c|c|c|c|c|c|c|}
\hline 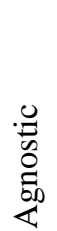 & 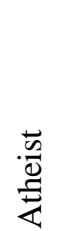 & 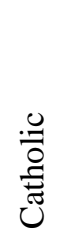 & 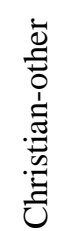 & $\frac{\sqrt[5]{5}}{3}$ & 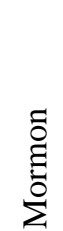 & $\begin{array}{l}\bar{z} \\
\overline{\bar{\Delta}} \\
\overline{0}\end{array}$ & 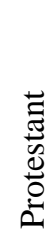 & 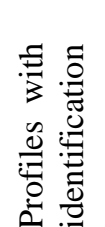 & 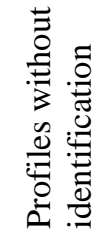 & స్తేర \\
\hline
\end{tabular}

NSYR affiliation

\begin{tabular}{|c|c|c|c|c|c|c|c|c|c|c|c|}
\hline Evan. Protestant & 1 & & 1 & $\begin{array}{l}\mathbf{1 3 6} \\
90 \%\end{array}$ & 1 & & $\begin{array}{c}6 \\
4 \%\end{array}$ & $\begin{array}{c}7 \\
5 \%\end{array}$ & $\begin{array}{c}152 \\
68 \%\end{array}$ & $\begin{array}{c}73 \\
32 \%\end{array}$ & 225 \\
\hline Main. Protestant & & 1 & & $\begin{array}{c}\mathbf{3 3} \\
87 \%\end{array}$ & & & 2 & $\begin{array}{c}\mathbf{2} \\
5 \%\end{array}$ & $\begin{array}{c}38 \\
64 \%\end{array}$ & $\begin{array}{c}21 \\
36 \%\end{array}$ & 59 \\
\hline Catholic & & & $\begin{array}{c}\mathbf{5 3} \\
86 \%\end{array}$ & $\begin{array}{c}\mathbf{8} \\
13 \%\end{array}$ & & & 1 & & $\begin{array}{c}62 \\
73 \%\end{array}$ & $\begin{array}{c}23 \\
27 \%\end{array}$ & 85 \\
\hline Jewish & & & & & $\begin{array}{c}\mathbf{5} \\
83 \%\end{array}$ & 1 & & & $\begin{array}{c}6 \\
100 \%\end{array}$ & & 6 \\
\hline Mormon/LDS & & & & 1 & & $\begin{array}{c}\mathbf{6} \\
75 \%\end{array}$ & 1 & & $\begin{array}{c}8 \\
73 \%\end{array}$ & $\begin{array}{c}3 \\
27 \%\end{array}$ & 11 \\
\hline Other $^{\dagger}$ & & & & 2 & & & $\begin{array}{c}9 \\
82 \%\end{array}$ & & $\begin{array}{c}11 \\
61 \%\end{array}$ & $\begin{array}{c}7 \\
39 \%\end{array}$ & 18 \\
\hline Agnostic & $\begin{array}{c}\mathbf{8} \\
53 \%\end{array}$ & 2 & & 1 & & & 4 & & $\begin{array}{c}15 \\
50 \%\end{array}$ & $\begin{array}{c}15 \\
50 \%\end{array}$ & 30 \\
\hline Atheist & 2 & $\begin{array}{c}9 \\
69 \%\end{array}$ & 1 & & & & 1 & & $\begin{array}{c}13 \\
72 \%\end{array}$ & $\begin{array}{c}5 \\
28 \%\end{array}$ & 18 \\
\hline Unaffiliated & 1 & 2 & $\begin{array}{c}7 \\
18 \%\end{array}$ & $\begin{array}{c}21 \\
47 \%\end{array}$ & 2 & & $\begin{array}{c}10 \\
22 \%\end{array}$ & & $\begin{array}{c}43 \\
39 \%\end{array}$ & $\begin{array}{c}65 \\
61 \%\end{array}$ & 108 \\
\hline tal & $\begin{array}{c}12 \\
3 \%\end{array}$ & $\begin{array}{l}14 \\
4 \%\end{array}$ & $\begin{array}{c}62 \\
18 \%\end{array}$ & $\begin{array}{c}202 \\
58 \%\end{array}$ & $\begin{array}{c}8 \\
2 \%\end{array}$ & $\begin{array}{c}7 \\
2 \%\end{array}$ & $\begin{array}{c}34 \\
10 \%\end{array}$ & $\begin{array}{c}9 \\
3 \%\end{array}$ & $\begin{array}{l}348 \\
62 \%\end{array}$ & $\begin{array}{c}212 \\
38 \%\end{array}$ & 560 \\
\hline
\end{tabular}

Note. Frequencies in bold indicate cells coded as consistent. All percentages calculated within rows. Percentages in italics are based on the total number of profiles that displayed a religious identification label. Percentages are not calculated for low-count cells.

${ }^{\dagger}$ Buddhist, Hindu, Jehovah's Witness, Muslim, Orthodox Christian, Unitarian Universalist, Pagan or Wiccan, Other. ${ }^{\dagger}$ Buddhist (1 consistent), Hindu, Muslim (1 consistent), Other (6 consistent), Scientologist, Taoist, Wiccan (1 consistent). 
Table 3

Regression Estimates of Relationships between Profile Owner Religiosity, Affiliation, and Religious SelfDisclosure (NSYR Wave 3 Respondents With Public MySpace Profiles, $N=560$ )

\begin{tabular}{|c|c|c|c|c|c|c|c|c|c|c|c|c|c|}
\hline \multirow[b]{3}{*}{ Variable } & \multicolumn{3}{|c|}{1} & \multicolumn{3}{|c|}{2} & \multicolumn{3}{|c|}{3} & \multicolumn{4}{|c|}{4} \\
\hline & \multicolumn{3}{|c|}{ Identification } & \multicolumn{3}{|c|}{ Quantity } & \multicolumn{3}{|c|}{ Identification } & \multicolumn{4}{|c|}{ Quantity } \\
\hline & $B$ & $S E B$ & OR & $B$ & $S E B$ & OR & $B$ & $S E B$ & IRR & $B$ & $S E B$ & OR & \\
\hline Gender (Female) & .18 & .19 & 1.20 & .03 & .10 & 1.03 & .23 & .19 & 1.25 & -.01 & .10 & .99 & \\
\hline Age & -.10 & .08 & .90 & -.05 & .04 & .95 & -.07 & .08 & .93 & -.05 & .04 & .95 & \\
\hline Ethnicity (White) & .23 & .21 & 1.25 & .37 & .12 & $1.44 * *$ & .17 & .22 & 1.18 & .35 & .12 & 1.42 & ** \\
\hline Family income & .03 & .04 & 1.03 & -.04 & .02 & $.96 *$ & .03 & .04 & 1.03 & -.04 & .02 & .96 & \\
\hline Education & .10 & .14 & 1.10 & .14 & .08 & 1.15 & .05 & .15 & 1.05 & .16 & .08 & 1.17 & \\
\hline Social net. frequency & .06 & .05 & 1.06 & .10 & .03 & $1.10 * *$ & .04 & .05 & 1.04 & .09 & .03 & 1.10 & $* *$ \\
\hline Overall self-disclosure & .49 & .09 & $1.63 * * *$ & $<.01$ & $<.01$ & $1.00 * * *$ & .50 & .09 & $1.65 * * *$ & $<.01$ & $<.01$ & 1.00 & *** \\
\hline Religiosity & .38 & .08 & $1.47 * * *$ & .42 & .05 & $1.52 * * *$ & .30 & .13 & $1.35 *$ & .34 & .07 & 1.41 & $* * *$ \\
\hline Mainline Christian $† \dagger$ & & - & & & - & & -.30 & .33 & .74 & -.57 & .18 & .56 & $* *$ \\
\hline Catholic & & - & & & - & & .19 & .31 & 1.21 & -.54 & .15 & .58 & $* * *$ \\
\hline Jewish & & - & & & - & & 1.31 & 1.17 & 3.69 & .04 & .43 & 1.05 & \\
\hline Mormon/LDS & & - & & & - & & .02 & .71 & 1.02 & -.42 & .34 & .65 & \\
\hline Other Religion & & - & & & - & & -.68 & .58 & .51 & -.19 & .32 & .83 & \\
\hline Agnostic & & - & & & - & & -.21 & .50 & .81 & -.60 & .33 & .55 & \\
\hline Atheist & & - & & & - & & .73 & .65 & 2.07 & -.08 & .37 & .92 & \\
\hline Unaffiliated & & - & & & - & & -.69 & .34 & $.50 *$ & -.41 & .20 & .66 & \\
\hline Intercept & -2.80 & 1.59 & - & -.67 & .80 & - & -2.84 & 1.65 & - & -.40 & .81 & - & \\
\hline $\operatorname{LR} \chi^{2}$ & & & $63.29 * * *$ & & & $46.45 * * *$ & & & $78.13 * * *$ & & & 69.03 & $* * *$ \\
\hline$d f$ & & & 8 & & & 8 & & & 16 & & & 16 & \\
\hline
\end{tabular}

Note. Logistic regression for identification; OR: odds ratio. Negative binomial regression for quantity; IRR: incidence rate ratio.

${ }^{\dagger}$ Overall identification for identification; overall quantity for quantity.

${ }^{\dagger}$ Evangelical Christian is the comparison category.

$* p<.05 . * * p<.01 . * * * p<.001$. 


\section{Table 4}

Regression Estimates of Relationships between Profile Owner Religiosity and Views of Religious Privacy, and Religious Self-Disclosure (NSYR Wave 3 Respondents With Public MySpace Profiles, $N=560$ )

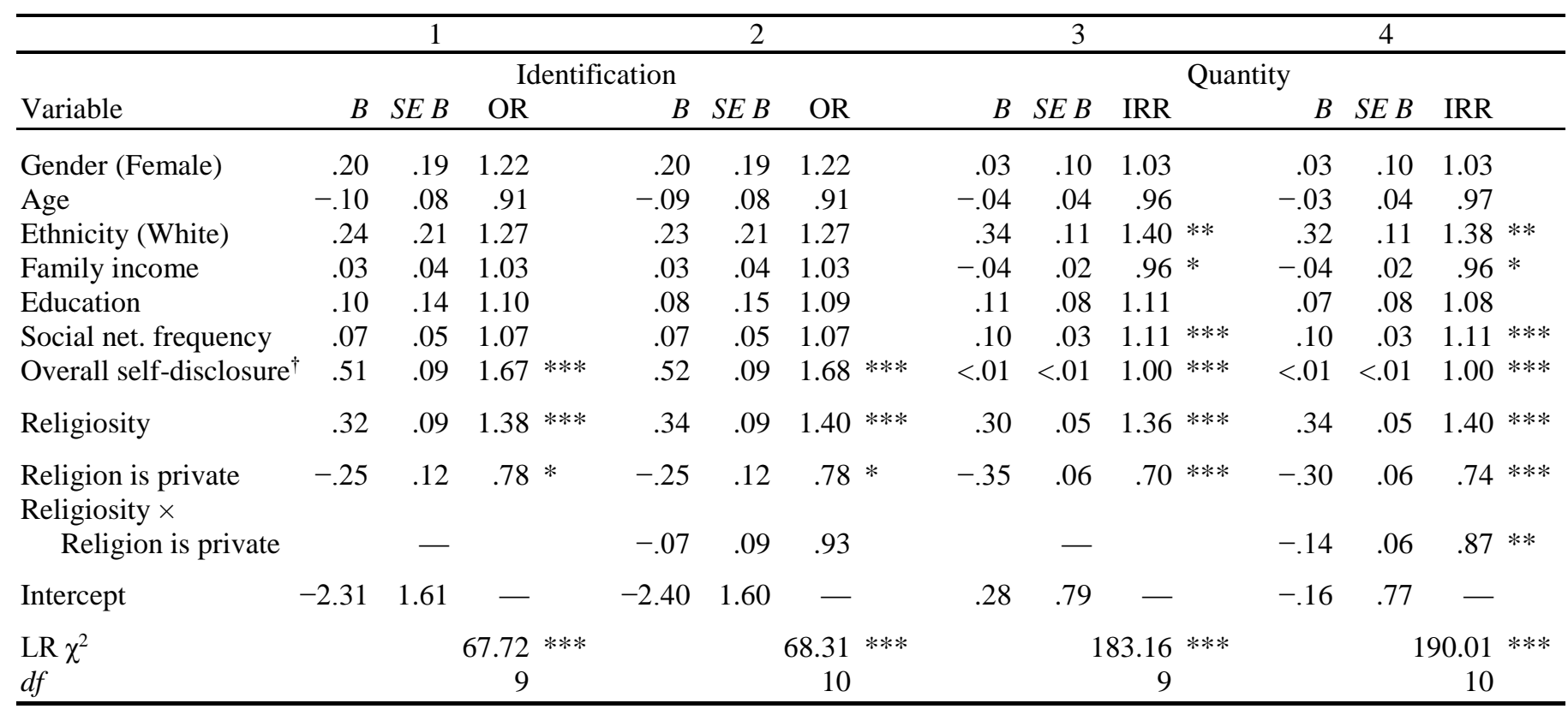

Note. Logistic regression for identification; OR: odds ratio. Negative binomial regression for quantity; IRR: incidence rate ratio.

$\dagger$ Overall identification for identification; overall quantity for quantity.

$* p<.05 . * * p<.01 . * * * p<.001$. 


\section{Table 5}

Regression Estimates of Relationships between Profile Owner Religiosity and Negative Perception of Organized Religion, and Religious Self-Disclosure (NSYR Wave 3 Respondents With Public MySpace Profiles, $N=560$ )

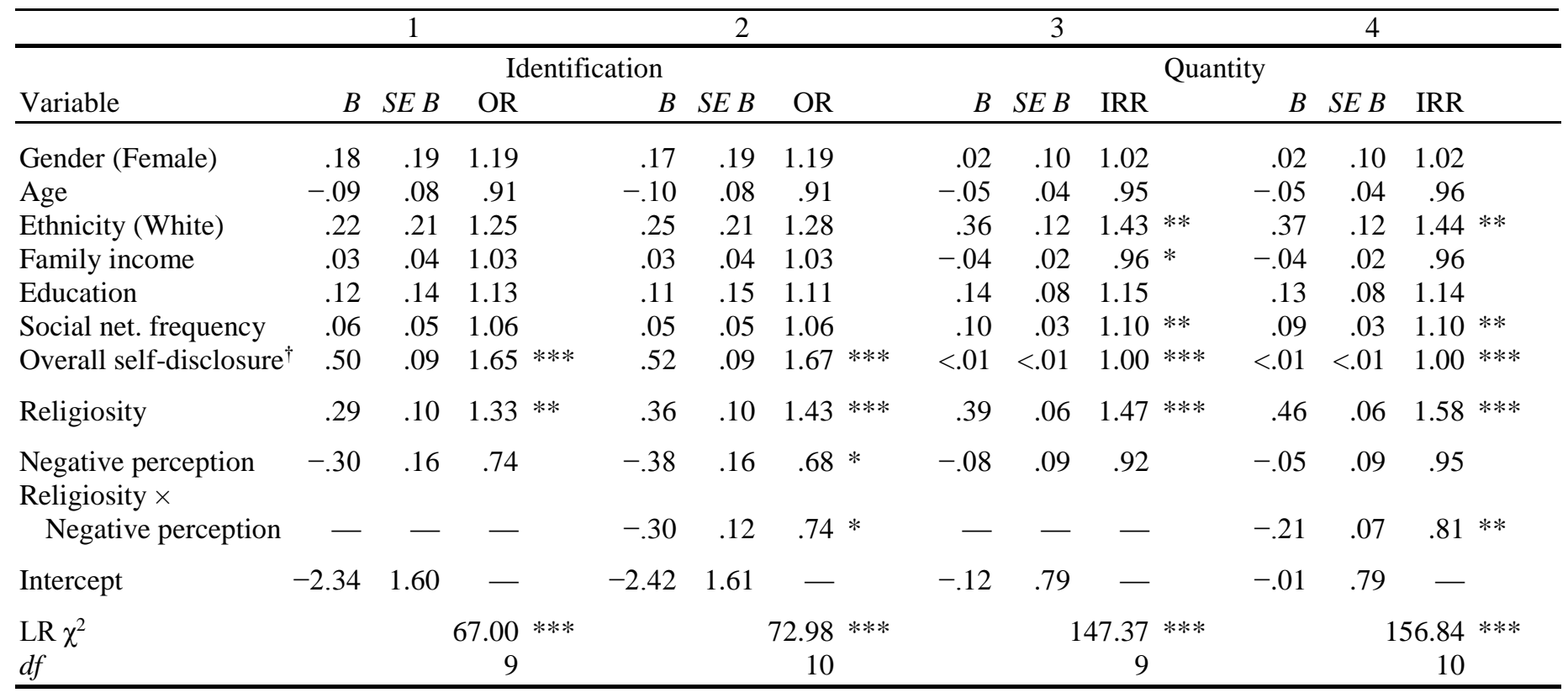

Note. Logistic regression for identification; OR: odds ratio. Negative binomial regression for quantity; IRR: incidence rate ratio. $\dagger$ Overall identification for identification; overall quantity for quantity.

$* p<.05$. ** $p<.01$. *** $p<.001$. 
Table 6

Regression Estimates of Relationships between Profile Owner Religiosity and Friendship Group Religiosity, and Religious Self-Disclosure (NSYR Wave 3 Respondents With Public MySpace Profiles, N = 560)

\begin{tabular}{|c|c|c|c|c|c|c|c|c|c|c|c|c|c|}
\hline \multirow[b]{3}{*}{ Variable } & \multicolumn{3}{|c|}{1} & \multicolumn{3}{|c|}{2} & \multicolumn{3}{|c|}{3} & \multicolumn{4}{|c|}{4} \\
\hline & \multicolumn{6}{|c|}{ Identification } & \multicolumn{7}{|c|}{ Quantity } \\
\hline & $B$ & $S E B$ & OR & $B$ & $S E B$ & OR & $B$ & $S E B$ & IRR & & $B$ & $S E B$ & IRR \\
\hline Gender (Female) & .18 & .19 & 1.19 & .18 & .19 & 1.19 & .03 & .10 & 1.03 & & .02 & .10 & 1.03 \\
\hline Age & -.08 & .08 & .92 & -.08 & .08 & .92 & -.04 & .04 & .96 & & -.04 & .04 & .96 \\
\hline Ethnicity (White) & .21 & .22 & 1.23 & .21 & .22 & 1.24 & .37 & .12 & 1.44 & $* *$ & .35 & .12 & $1.42 * *$ \\
\hline Family income & .04 & .03 & 1.04 & .04 & .04 & 1.04 & -.04 & .02 & .96 & $*$ & -.04 & .02 & .96 \\
\hline Education & .04 & .15 & 1.05 & .06 & .15 & 1.05 & .10 & .08 & 1.11 & & .09 & .08 & 1.10 \\
\hline Social net. frequency & .06 & .05 & 1.07 & .06 & .05 & 1.07 & .10 & .03 & 1.10 & $* *$ & .10 & .03 & $1.11 * * *$ \\
\hline Overall self-disclosure & .51 & .09 & $1.67 * * *$ & .51 & .09 & $1.67 * * *$ & $<.01$ & $<.01$ & 1.00 & $* * *$ & $<.01$ & $<.01$ & $1.00 * * *$ \\
\hline Religiosity & .23 & .09 & $1.26 *$ & .23 & .09 & $1.26 *$ & .29 & .05 & 1.33 & $* * *$ & .30 & .05 & $1.34 * * *$ \\
\hline $\begin{array}{l}\text { Friendship grp. rel. } \\
\text { Religiosity } \times\end{array}$ & 1.09 & .28 & $2.99 * * *$ & 1.09 & .28 & $2.98 * * *$ & .80 & .15 & 2.23 & $* * *$ & .77 & .16 & $2.17 * * *$ \\
\hline Friendship grp. rel. & - & - & - & -.03 & .24 & .97 & - & - & - & & .17 & .15 & 1.19 \\
\hline Intercept & -2.42 & 1.61 & - & -2.39 & .27 & - & .08 & .78 & - & & -.01 & .78 & - \\
\hline $\begin{array}{l}\operatorname{LR} \chi^{2} \\
d f\end{array}$ & & & $\begin{array}{c}79.48 * * * \\
9\end{array}$ & & & $\begin{array}{c}79.49 * * * \\
10\end{array}$ & & & $\begin{array}{r}73.71 \\
9\end{array}$ & $* * *$ & & & $\begin{array}{c}75.13 * * * \\
10\end{array}$ \\
\hline
\end{tabular}

Note. Logistic regression for identification; OR: odds ratio. Negative binomial regression for quantity; IRR: incidence rate ratio.

$\dagger$ Overall identification for identification; overall quantity for quantity.

$* p<.05 . * * p<.01 . * * * p<.001$ 
(a) Predicted probability of religious identification

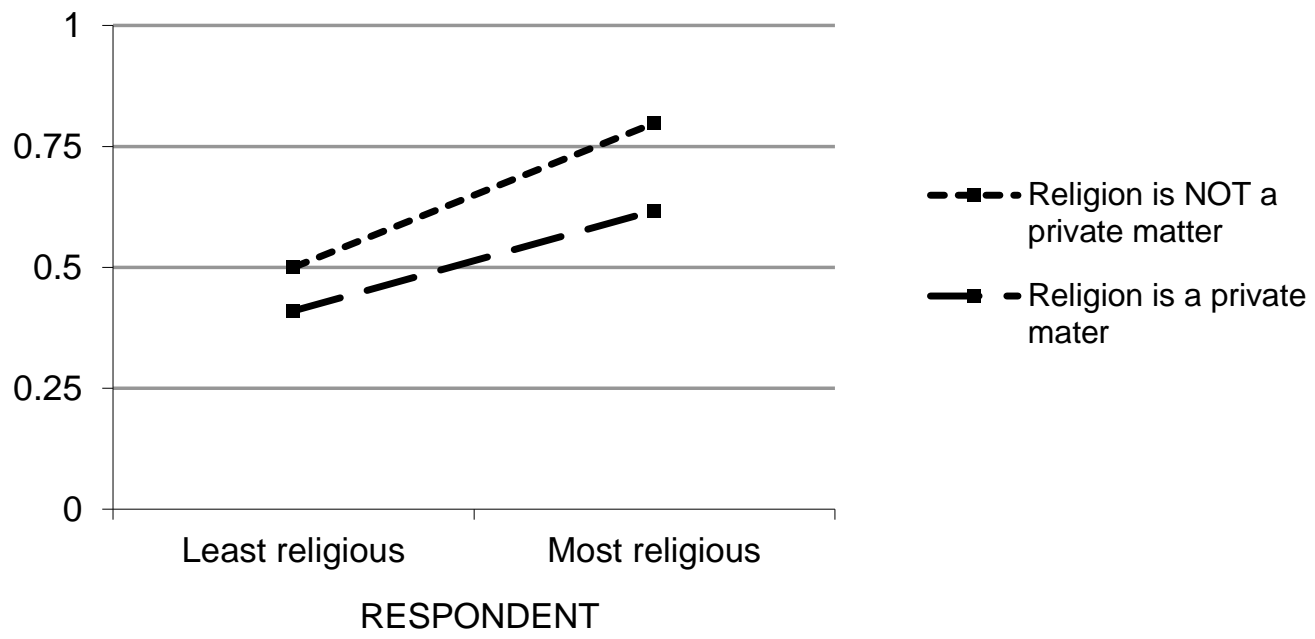

(b) Predicted quantity of religious self-disclosure

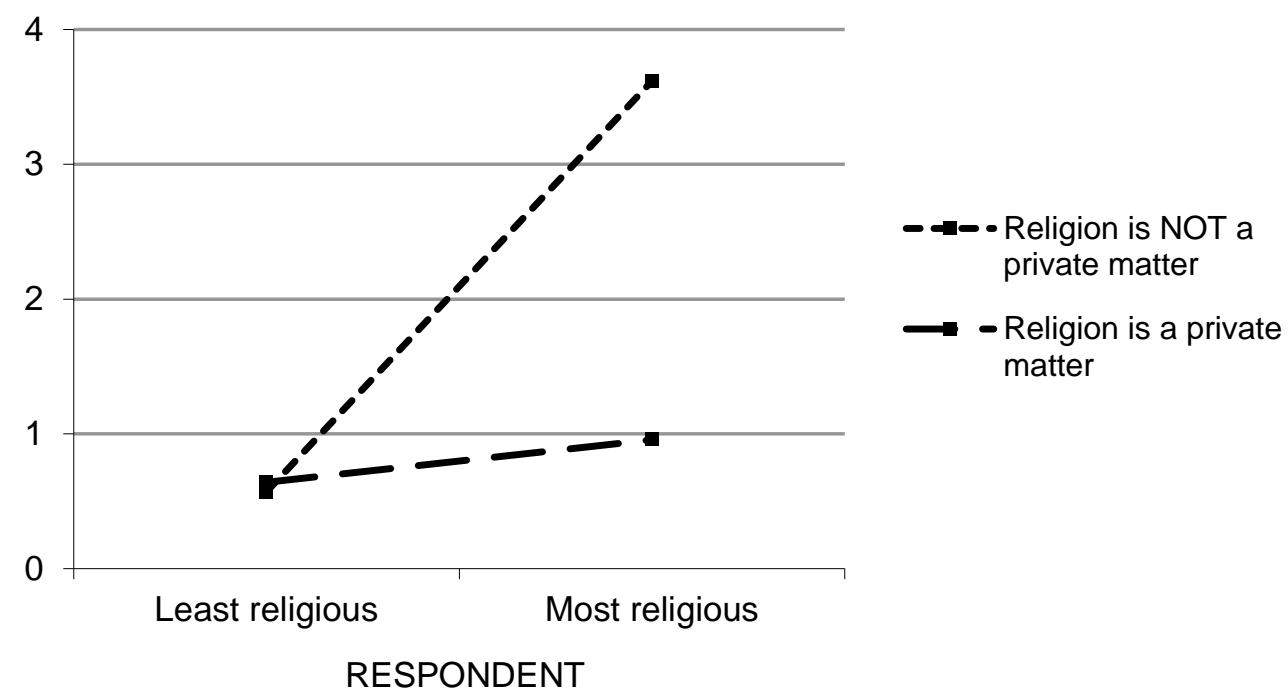

Figure 1 Predicted religious self-disclosure as a function of religiosity and attitude about the privacy of religion 
(a) Predicted probability of religious identification

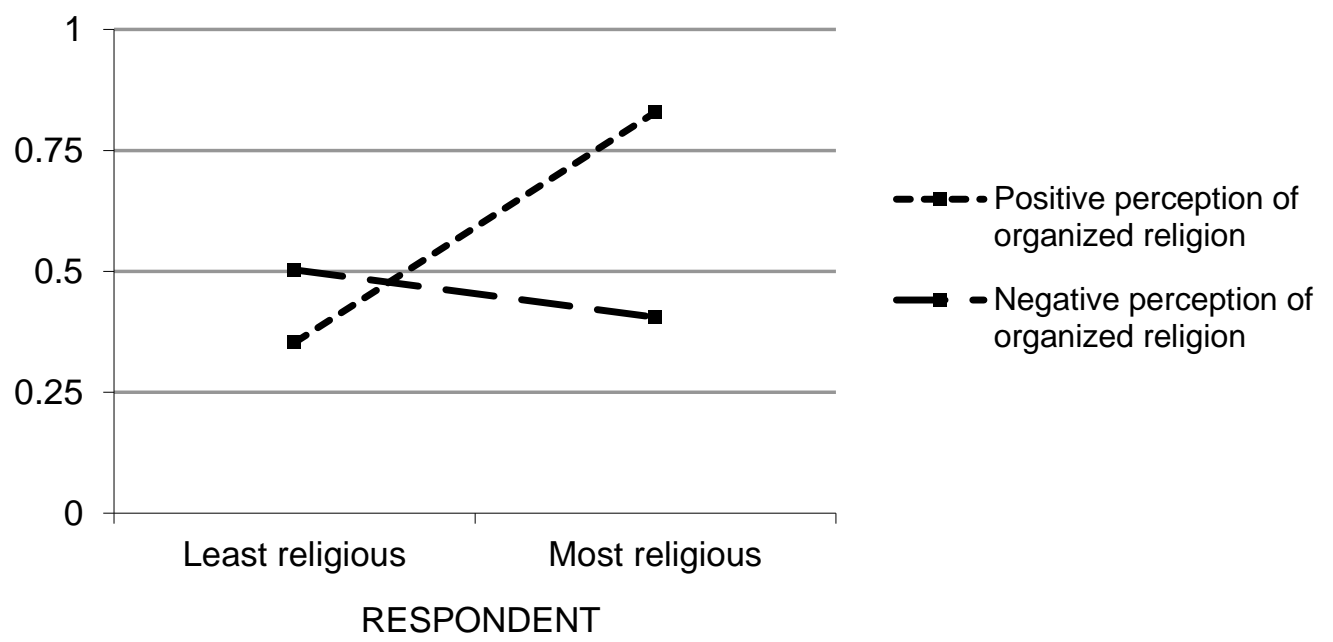

(b) Predicted quantity of religious self-disclosure

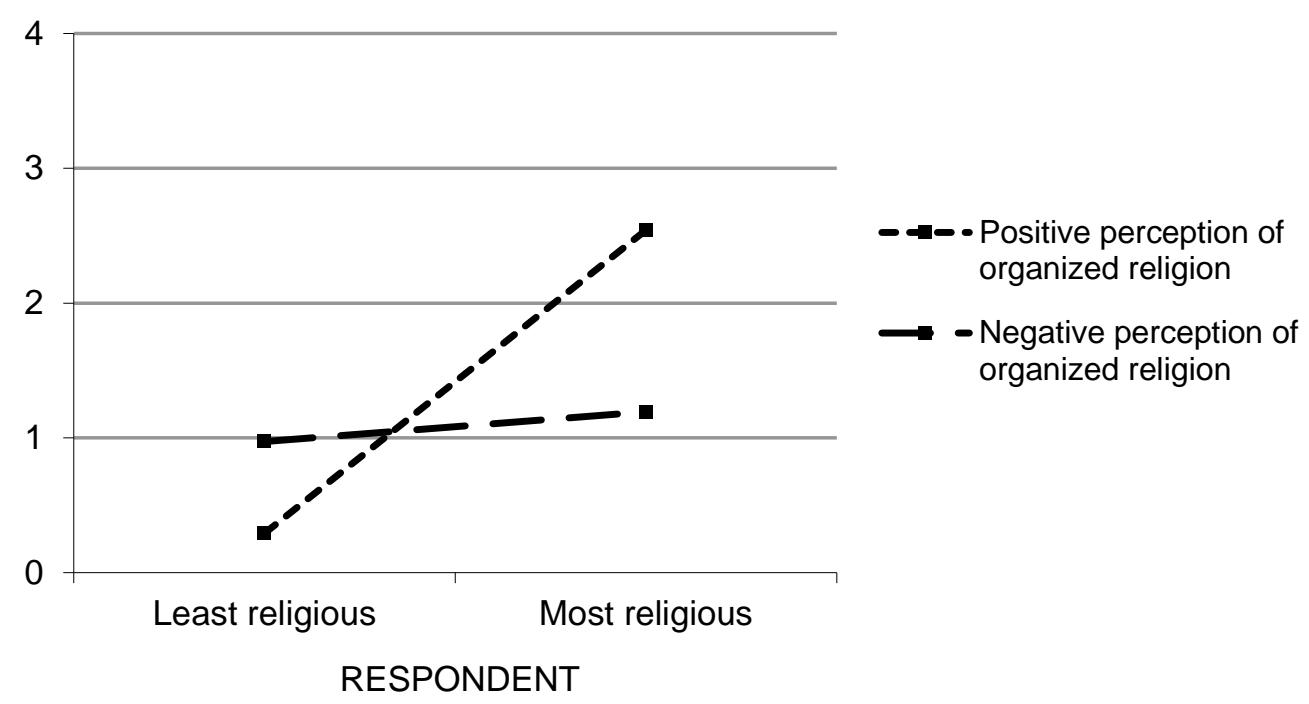

Figure 2 Predicted religious self-disclosure as a function of religiosity and attitude about negative perception of organized religion 
(a) Predicted probability of religious identification

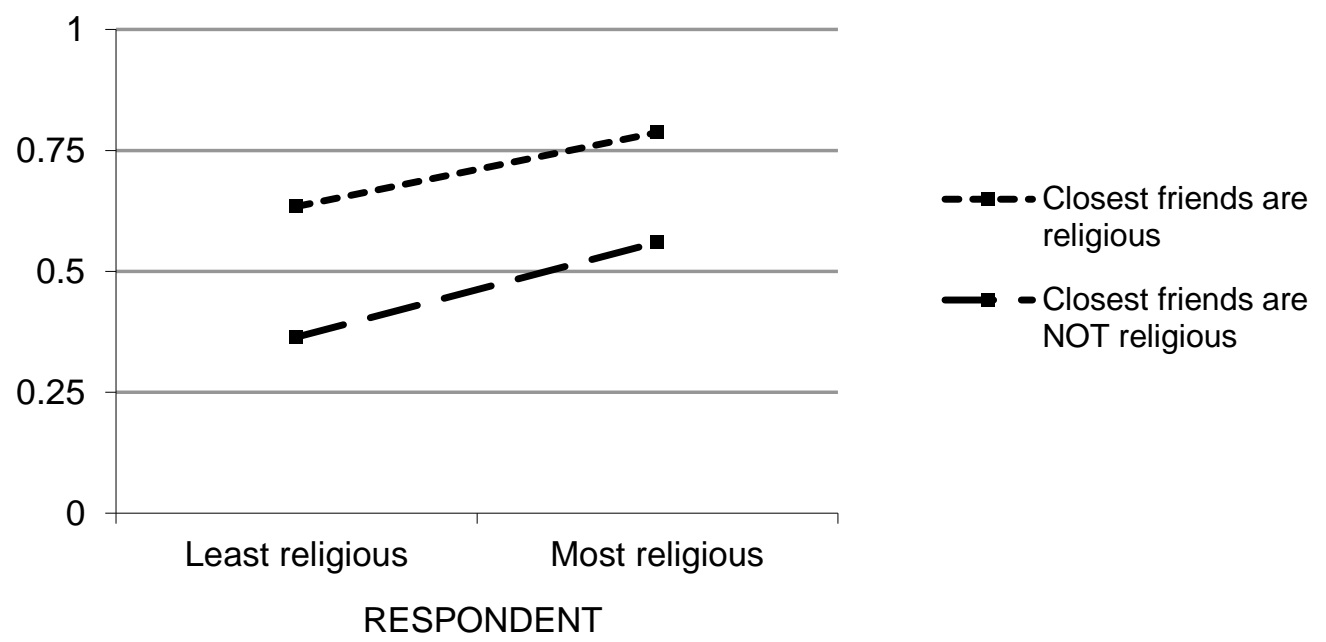

(b) Predicted quantity of religious self-disclosure

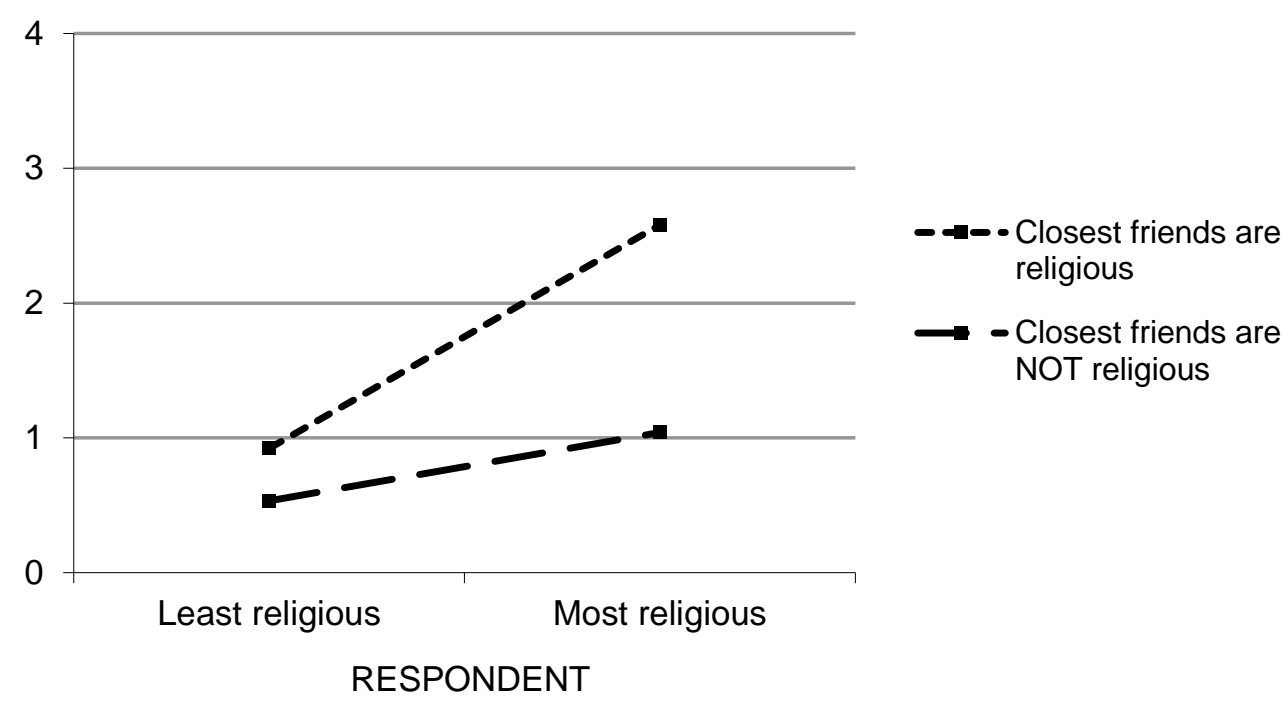

Figure 3 Predicted religious self-disclosure as a function of religiosity and friendship group religiosity 